\title{
Sacrifice and Signification in the Poetry of Allen Curnow
}

\author{
Alex Calder
}

\section{CEREMONIAL}

At Athens, Lysimache, the priestess of Athene Polias, when asked for a drink by the mule drivers who had transported the sacred vessels, replied, "No, for I fear it will get into the ritual."

- Plutarch ${ }^{1}$

Poetry won't bear too much accidental stuff, but must have some. Warning: do not exceed the stated dose.

Lysimache, like Allen Curnow, is a true master of ceremonies. Those mule drivers stay thirsty precisely because a ritual won't bear too much accidental stuff. Just as a poet, according to Curnow, "never stops trying to save poetry from poetry, to make something of it, not a spurious everything," so must the priestess regulate ritual's appetite for the consumption of signs. ${ }^{3}$ For both poet and priestess, mastery means maintaining an economy of signifi- 
cation, and yet that mastery is always already in jeopardy: the medium each works in has the capacity to signify endlessly. What say those mule drivers did exceed the stated dose? The priestess might look to sanctions or corrections, some rite that would protect the unclean and the ritual itself from the consequences of inadvertent defilement. And if a poet were to ignore Curnow's warning? Indifference to an economy of signification risks banality or delirium - but, given that poetry must have some "accidental stuff," what rites, what correctives, maintain that economy? And at what cost are constraints against unlimited semiosis maintained? In answering these questions-or, more exactly, establishing them as questions Allen Curnow's poems answer, and answer variously-I have been interested by something else the poet and priestess have in common. It is a kind of professional expertise in matters relating to sacrifice, to the victims each, in a sense, "needs for their work," victims both poet and priestess may partly resemble.

But first, I would like to tell you the story of another such victim. She is one of Freud's "obsessional neurotic" patients and the behaviour she exhibits is the sort psychologists still term, "ceremonial." The patient, he writes:

used to repeat an especially noticeable and senseless obsessive action. She would run out of her room into another room in the middle of which there was a table. She would straighten the table-cloth on it in a particular manner and ring for the housemaid. The latter had to come up to the table, and the patient would then dismiss her on some indifferent errand. In the attempts to explain this compulsion, it occurred to her that at one place on the table-cloth there was a stain, and that she always arranged the cloth in such a way that the housemaid was bound to see the stain. The whole scene proved to be a reproduction of an experience in her married life which had later on given her thoughts a problem to solve. On the wedding-night her husband had met with a not unusual mishap. He found himself impotent, and "many times in the course of the night he came hurrying from his room into hers" to try once more whether he could succeed. In the morning he said he would feel ashamed in front of the hotel housemaid who made the beds, and he took a bottle of red ink and poured its contents over the sheet; but he did it so clumsily that the red stain came in a place that was very unsuitable for his purpose. With her obsessive action, therefore, she was representing the wedding-night. "Bed and board" ["Tisch und 
Bett" ] between them make up a marriage. ${ }^{4}$

One of the more famous lines in New Zealand poetry - "the stain of blood that writes an island story"-also happens to be written in ink. ${ }^{5}$

"Landfall in Unknown Seas" is a ceremonial poem: it commemorates the three-hundredth anniversary of Tasman's discovery of New Zealand. The poem has two themes, only slightly distinct from each other. One is a meditation on discovery and the epistemological distinction between map and territory. Territory, be it a stretch of coast or the Real, is always already "something different, something nobody counted on."6 What we do count on, all we can count on, are our maps. These might be as vague as the expectations that brought Tasman on his voyage or as rich as the faculties of language and perception, but they are maps all the same, and we mistake the categorical difference between map and territory at our peril. The second theme concerns the fact that the first encounter between the discoverers and those who discovered them was bungled: the day was "marred with murder," blood flowed, and its traces and substitutes leave the poet, like the patient, with a problem to solve. Already we might see how the second theme is an emblematic version of the first: the stain of blood that writes an island story issues, as it were, from the gap between map and territory. But I think something more is involved, and we might let Freud's patient be our guide.

Freud himself has only a little to say. The woman's ceremonial, he notes, shows a minutely detailed identification with her husband. Her actions follow the logic of wish-fulfilment, transforming what didn't happen into what should have happened; and because the stain, through displacement, is now "in the right place," her husband, says Freud dryly, "is made superior to his past mishap."7 The last lines of "Landfall in Unknown Seas" might similarly propose a metonymic act of identification.

Only by a more faithful memory, laying On him the half-light of a diffident glory, 
The Sailor lives, and stands beside us, paying

Out into our time's wave

The stain of blood that writes an island story.

In this moment of identification, the mantle of a sacrificial victim is laid on the dead sailor so that he, too, is "made superior to his past mishap." In this, a wish is fulfilled - one that concerns, not the sailor, but rather the present of the poet's discourse. Much of the third section of "Landfall in Unknown Seas" is a catalogue of inadequate and white-washing responses to the events the poem commemorates. Set against "those speeches / Pinning on the Past like a decoration / For merit that congratulates itself" is the poet's "more faithful memory." The poem insists on the distinction, but it is only in wish that these can be kept separate, a wish accompanied by sacrificial violence.

Let us consider, once more, the patient's story. The honeymoon night is a conventional occasion, and its signs, once part of an older signifying system, now inform a nineteenth century code of male pride. That night something unexpected happens (ie. nothing happens), and this accident leads to an attempted correction and a crisis for signification. Suppose, for a moment, the housemaid did pay particular attention to those ink stained sheets. While I have little expertise in the semiotics of laundry, I expect she would have read a highly ambiguous message. She might imagine all sorts of contexts-hardly any of them erotic-in which the ink just happened to spill. She might also have read an attempt to deceive. In this case, the husband's impotence is only one explanation for the absence of blood and the presence of ink; the possibility that his bride was already "used goods" is another.

What has happened is that a connotative chain-bloody sheets signify a properly consummated marriage- - has been damaged; the attempt to repair it, however, only succeeds in highlighting its denotative elements. The ink, signifying bloody sheets signifying a properly consummated marriage, doesn't signify; it remains, palpably, embarrassingly, ink. The resulting proliferation of possible meanings is then limited and controlled in the wife's cer- 
emonial through an interplay of repetition and victimage. The husband's reputation is wishfully restored, the signifying system is stabilised, but at a price: the wife can only cast herself as a victim - both of the past she repeats and cannot understand, and of the reproach that may, in all likelihood, underlie her identification with her husband, the unfair reproach of a victim who feels, "it was all my fault."

I think "Landfall in Unknown Seas" follows a similar trajectory. The story it tells follows a sequence whereby the hubris and high hopes of discovery founder on an unexpected event; a story, I have suggested, the poem allegorises in terms of the distinction between map and territory. But there is a point where the poet's discourse also meets with an accident, one that reflexively poses a crisis for signification and requires a restoration of its economy. The poem begins:

Simply by sailing in a new direction You could enlarge the world.

So far, the poet has made no reference to territory. An opening irony implies that whatever discovery is or entails, it is not going to be simple. As for what is to be found, a term denoting territory - "the world" - is used here as a figure for knowledge, for our maps. The metaphor is particularly effective because it overlays a metonymy-one thinks of the kind of map on which the words "Terra Incognita" might appear, a map-of-the-world that might be enlarged or redrawn, by sailing in a new direction.

This complex of figurative meanings meets with an accident in the poem's final section:

Well, home is the Sailor, and that is a chapter

In a schoolbook, a relevant yesterday

We thought we knew all about, being much apter

To profit, sure of our ground,

No murderers mooring in our Golden Bay.

In a poem so interested in maps and territories, the historical substitution of names-Mur- 
derer's Bay becomes Golden Bay-just had to be mentioned, but mentioning it proves to be a snare. Is the new name more like the territory (where the sands underfoot are indeed "golden"), or does the substitution involve a lack of fidelity to the real? Neither question is appropriate: a change of place names is entirely in keeping with the rule, "The map is not the territory and the name is not the thing named." 8 Yet the tone of the poem is clearly derisory. It is as if the speaker has now taken his opening lines-"simply by sailing in a new direction / you could enlarge the world" - not figuratively, but denotatively; as if, in changing the place name, the territory has somehow been damaged, not "enlarged," but shrunk through this sanitising occlusion of the reality of past violence. The result is a loss of ground: everything becomes writing, only writing: "a chapter in a schoolbook," a speech "pinning on the Past like a decoration for merit that congratulates itself," a "self-important celebration" a "painstaking history."

This is the horror of unlimited semiosis. Meaning either proliferates endlessly - as in the list of writings—or, arrives at a condition of null semiosis: "here is the world's end where wonders cease." The alternative is the poet's "more faithful memory" - a memory that can only wishfully be kept separate from writing. This moment of identification, I suggested earlier, makes the sailor a sacrificial victim. It has another function too: it limits semiosis. When the speaker has the sailor stand Christ-like beside us, "paying / Out into our times wave / The stain of blood that writes an island story," he has at last arrived at a stable meaning-"we are all victims in time" - a stability that requires an act of sacrificial transubstantiation, turning, not wine into blood, but ink into "the stain of blood that writes an island story." 


\section{THE UNSPEAKABLE}

There was a man in Boston who was so large when a babe that it was impossible to name him all at once.

-Anon. ${ }^{9}$

Names and dimensions are two distinct logical types, but our facility for nonsense allows us to mix them, to think names and sizes on one equivalent plane. The humour of this old joke is hardly transgressive: it relies on and confirms the distinction it plays with, is funny, perhaps, precisely because it calls such a distinction to mind. But what about this?

Tane Mahuta is a very big tree because of the signboards at the roadside.

Or this?

No nativity ode for Tane. At his namegiving

nobody had the time, having time only short of an unspeakable supervention

to blurt him, Logos begotten of log, the disyllable, as he came..$^{10}$

The machinery of humour is there in both cases. The first, like a chicken crossing the road joke, springs a context surprise, the second puns on a word written within the Word. But these are serious jokes: they evaporate laughter and unsettle, rather than confirm, the categories of sense.

As that pun promises, "A Four Letter Word"-from the 1972 sequence, Trees, Effigies, Moving Objects - is something of a tall story about the origin of language. Is the title a clue to that origin? If "A Four Letter Word" suggests to you the sort of word that begins with an F and ends with an UCK, you will have been the victim of a "firetruck" joke: the poem's four letter 
word turns out to be "Tane," the name of a tree, the name of a god. And yet Tane's name, we just heard, was not given but blurted-it is an expletive. What is the origin of language? A four letter word. The logic that takes us there is almost palindromic-like "Madam I'm Adam," a game of mere writing. But, like the poem's other jokes in and about writing, these games seem on the point of breaking the circle that contains them. For instance, when "Logos is begotten of log," the pun is not merely graphematic: it is as if a sign has been broken, sawn off, revealing a natural origin at the heart of all naming.

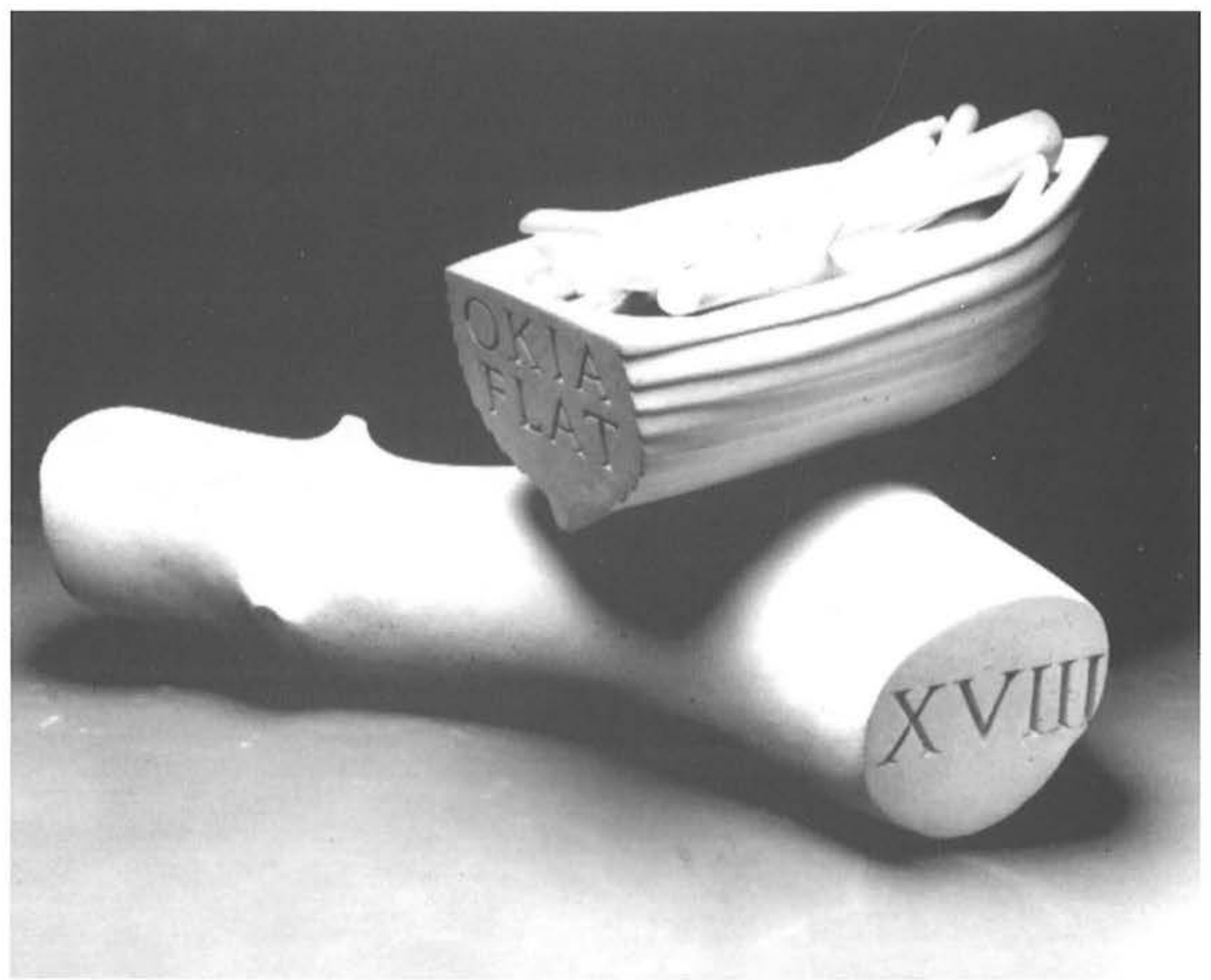

Denis O'Connor, Oarnest 1985, South Island limestone. 
The idea is scandalous, but it is worth noting that there was a linguist-manqué who arrived, in all earnestness, at a theory very like this, in a manner somewhat like this. In La Science de Dieu, Jean Pierre Brisset located the origin of human language in the croaking of frogs. His evidence was a kind of energetic etymology. Brisset would take a word, logé (lodged) for instance, and find other words "inside" it, such as: "l'eau j'ai" (I have water), "l'haut j'ai" (I am high), "l'os j'ai" (I have a bone). This string of revealed words told him that man's ancestor, the frog, was carnivorous and lived by the water in lake villages built on posts a detail confirmed by the Greek, if Logos is begotten of log. According to Jean-Jacques Lecercle, Brisset's wild etymologies generate a "real but diseased creation myth": "Beneath the veneer of Brisset's grammar," he writes, "there soon emerges the violent story of how the frog became man, an epic of cruelty and pain, of war and cannibalism, a tale told by a prophet, full of croaks and fury, signifying much."11

But what makes the one about the baby from Boston so different from Curnow's tall story or Brisset's delirium? We know, without even thinking, not to confuse the size of a baby and the size of a name, yet it will take an effort of thought-perhaps even an impossible effort of thought-to avoid positing some kind of natural link between names and the things they refer to. Saussure's great insight-that "in language there are only differences without positive terms" - may be unimpeachable linguistics, but it contradicts all our deepest intuitions about who and what and where we are. ${ }^{12}$ Perhaps, acknowledging a debt to Brisset, we should read Curnow's poem as a story, not of the origin of language, but of the origin of our contradictory experience of language - a true story, I might add, of violence and desire, of the sacrificial dismemberment of the body.

The poem begins:

A wood god bothering cantor rolls out his call. He names tanekaha, kaiwaka, taraire. Mispronounced, any of these 
can strike dead and dumb. Well spoken, they are are a noise neither of the writhing root

nor glabrous leaf nor staring flower, all that can unspeakably supervene.

When the well-spoken cantor rolls out his call, what he names—-tanekaha, kaiwaka, taraireare conventional signs. This is a simple rule: the materiality of the signifier is not to be confused with the materiality of that which is signified; one does not water the name of a plant. Rather, the names denote or refer; if the well spoken word "strikes," hits its mark, this is merely an effect language is capable of achieving and not the model or basis of a relation beyond that effect. ${ }^{13}$ What lies outside language is literally unspeakable. Indeed, the very notion of an outside is a construct of language: in the poem's words, extralinguistic reality "supervenes," not intervenes, it follows upon the establishment of language.

It would seem that the poet has set in place the firmest of distinctions between linguistic and extralinguistic reality. At the same time, however, he adds a contrasting scenario, one that qualifies the force of that initial distinction. He suggests there is a difference between good and bad naming, between the possibility of the cantor calling the tree by name and the possibility of his mispronouncing it. A mispronounced name- $\mathrm{I}$ am thinking of something worse than "tanny-kaha" - "can strike dead and dumb." A name like that is just noise, it has lost its power to "strike" or refer. If good naming is like a bell that rings out when struck, the mispronounced name might simply go "clunk." The difficulty here is that sound does not change in accordance with reference: "dead and dumb" strictly describes the well spoken name (as signifier) too. To overlook that would seem to give the well-spoken name something extra, some attribute the mispronounced name lacks or loses. But neither the signified nor that which is signified is an attribute of the signifier: the poem's countersuggestion is a first mark of resistance to the arbitrariness of signs. Further, the phrase "can strike dead and dumb" might also suggest a fate that befalls the mispronouncer of names. 
But if linguistic transgression is an instance of "unspeakable" behaviour-an act that places a speaker beyond the pale-we again have a conflation of categories appropriate to linguistic and extralinguistic reality. It is as if the dead and dumb mispronouncer were to join the alterity of glabrous leaf and staring flower. But note the overkill of the phrase "dead and dumb." Redundancy in punishment, I would suggest, is often the lot of those who break taboos. Extralinguistic reality and linguistic transgression ought to be distinct logical types, but mixing them has a singular advantage. While the suggestion is barely made as yet, it prepares the way for a scenario in which the taboos and violence associated with transgression become guarantors of a more than conventional relation between language and the world.

In the poem's second section, we move from speech to writing, from the Cantor's act of naming to another mode of discourse the poet associates with advertising. This shift is profoundly defensive, for what is mocked here is by no means a special and degenerate case: it is characteristic of language as such.

Tane Mahuta is a very big tree, because of the signboards at the roadside.

Tired trunk, punky at the heart, disyllabic Tane is too venerable

for words. True, that at a given sign they stop their cars and walk no distance

to have seen, to have found themselves, as advertised, in the absence of the god,

to have decently exposed some inches of film in honour of his great girth.

Strike him with lightning! the old arboreal bore. 
Cut him up for signboards. Just look at that, such longevity, such bulk, such value in board feet.

Driving through Northland you might pass a roadsign that said, "To Big Kauri." And the tree is big because of the sign: Like the cheese label's "bigger block," the sign does not refer to a dimension, it promises better value, more "tree" for one's money and time. Such a tree is exactly as real as the photographs tourists take of it-it belongs, not to the order of objects, but to the order of simulacra, of "effigies." The poem's satire works by literalising the loss of the referent. Tane is "too venerable for words," he is old, punky at the heart, and boring; he might as well be cut up for signboards since this is all he has come to. But, as I hear it, the humour is sardonic and implies this is indeed a loss to be mourned. When the referential or "well-spoken" word falls, as a tree or Adam might fall, into mere sign value, the distinct becomes the same and what once seemed to have ground is plunged into groundlessness. If the tone implies a positive alternative to the prospect of unlimited semiosis, the poet will have to invent one. There is nothing unusual in this: we all encounter situations in which meaning seems to proliferate and we cope, often enough, by trying a new context. The poet's next move, then, will be to recontextualise his initial scenario of naming. He needs somehow to find a context that falls "in between" a naive cratylism he cannot support and the insupportable implications of a language that has always already lost its ground in reference. He does this by way of a swerve into mythology, by making a totem of Tane.

Titans were titanic in the old days before the defoliant Thunderer.

The children had no fathers then, as now.

No nativity ode for Tane. At his namegiving

nobody had the time, having time only

short of an unspeakable supervention 
to blurt him, Logos begotten of log,

the disyllable, as he came.

The myth is highly syncretic and I mean to reply in kind. First, I suggest we associate those "old days" with a particular point in the Greek creation myth. Kronos has castrated his father, Uranus, but will in turn be displaced by Zeus, "the defoliant Thunderer." In the meantime, he gobbles up his titanic offspring as fast as they are born. Suppose Tane is numbered among these; suppose, too, that as he is born there is time, "short of an unspeakable supervention," for something new to come about: the birth of difference and exchange. This might be thought of as a passage from tautology ("the titans were titanic") to the pun ("Logos begotten of $\mathrm{Log}^{\prime \prime}$ ), and from undifferentiation ("the children had no fathers...") to the disyllable, Tane, a first diacritical mark on which all other discriminations-kinship, taboos, the nature-culture distinction-rely.

In a formal sense, the pun is associated with difference, with the Brisset-like possibilities of unbridled semiosis. Yet "Logos begotten of $\log ^{\prime}$ is also a pun that reclaims, again like Brisset, the solid ground of natural reference. On the one hand, language as differential system, on the other, its grounded transparency to the objects of nature. Our everyday experience of language straddles just such a contradiction: its implications, consequences, "origins," might be developed more clearly in relation to an analogous system of signification-that of the totem.

Imagine a culture in which one group of people identify with the Kauri as totem, other groups with the Tanekaha, Kaiwaka and Taraire. A member of the Kauri clan would not, or not without ritual precautions, chop down a Kauri, but he or she does make free use of all the other trees in the forest. Similarly, intermarriage is prohibited within a clan, permitted without. Indeed, all manner of rites and practices, from name giving through to the care of the dead, hinge on the totemic differentiation of trees. According to Levi-Strauss, the totemic institutions of such a culture are "based on the postulate of a homology between two 
systems of differences, one of which occurs in nature and the other in culture."14 The system is purely formal: Kauri clan members differ from those of the Tanekaha clan as for instance the Kauri tree differs from the Tanekaha tree. But this system of formal differences is felt and lived out in terms of resemblance, it being well known, for instance, that Kauri clan people have their heads in the clouds and are inclined to be hard of heart.

We have already heard the story the Kauri clan tell of Tane's birth and name giving: in a moment the poet will return to that scene, but now he comments on the culture that invented the myth, and compares it with his own.

In the technologies nothing can be done without a divine sub-contract:

this one for the felling, the hollowing, prone canoe, erected post;

Tane demiurgos, lord of an obsolete skill:

not to keep an old man ticking with a dead boy's heart

(cut while warm, after the crash, pray for this tissue not to be rejected);

an instance now, look at it like that, of what can unspeakably supervene....

The poem began by positing a tension - if not a divide- between linguistic and extralinguistic reality. The totem, Tane Demiurgos, maker of the world, offers one resolution of that problematic relation. His line of ancestry-Logos begotten of log-is a mythical statement about a logical relation, a totemic code that organises homologies between distinctions in nature and distinctions in culture. But the totem also institutes a system of prohibitions and permissions-"divine subcontracts" or ceremonies that accompany exchange from nature 
(the tree) to human artefacts (canoes, posts). And then, a startling transition, from the "obsolete" to the technologies of modern surgery.

We might ask a simple question: why heart transplants? The selection of this detail provides the most vivid of contrasts between modern and totemic technologies, but it is a contrast that points, not to the obsolescence of old patterns of thinking, but to their currency. The heart transplant is an operation that mediates between life and death, that effects an exchange between these two realms. One reason, perhaps, why these lines are introduced by a syntactically uncertain "not," a prohibition soon to be balanced by the ritual supplication, "pray for this tissue not to be rejected"; one reason, again, why the operation-the heart "cut while warm" -is made to seem as bloody a sacrifice as any offered to a totemic god. And yet, the heart transplant has another set of motivations as well. The detail is metonymically derived - transplanted - from earlier sections in the poem. Tane, the very big tree, is old; like the recipient of the transplanted organ, he is "punky at the heart." As for the donor, the medical practice of cannibalising a corpse for its reusable parts recalls the myth of Kronos, of the old man who feeds on his sons. Our initial question-why the heart transplant?could do with a reformulation: why are textual exchanges so curiously dovetailed with the operation as a sacrificial ceremony of exchange?

We asked a similar question of "Landfall in Unknown Seas." Violence, I suggested then, constrains semiosis, it gives one the sense of a ground when groundlessness threatens. But this poem will become more violent yet. And, as it joins its end to the story of Tane's birth, it will not only develop a myth of origin that restates questions of sacrifice and signification as questions of the body, it should also allow us to speak the unspeakable's name. The poem continues:

an instance now, look at it like that, of what can unspeakably supervene, ever since like cats in the dead of night the first heaven and the first earth 
coupled and begot,

and the theogonies littered the place

with the lordliest imaginable

stumps. That's life. That's fear

of this unspeakable that smashed the mouth

open, stamped on the balls and

ripped from the tongue's root, womb syllabled,

Tane, Tane mahuta.

The closing lines are a return to and amplification of the poem's third section. I suggested then that we interpret the time between Tane's birth and the "unspeakable supervention" as a moment in a Kronos myth: first a birth, then the briefest of intervals, and now - the closing lines returning us to the scene - the birth as a kind of dismemberment. The logic of that sequence may become clearer by considering, once again, the Kauri people whose creation myth, we may imagine, this is. The myth tells, not only of the birth, but also of the premature death of their totemic ancestor. This is curious because every member of the Kauri clan claims descent from Tane - their system of exogamy is based precisely on this "fact" - and yet the totemic ancestor, it would seem, is given no opportunity whatsoever to be a genealogical ancestor. Levi-Strauss comments:

Totemism, as in certain games of patience, lays all its cards on the table at the beginning of play: it has none in reserve to illustrate the stages of transition between the animal or vegetable ancestor and the human descendent. The passage from one to the other is thus necessarily conceived as discontinuous ... a veritable "scene-shifting" without dropping the curtain, which excludes all perceptible contiguity between the initial and the final states. ${ }^{15}$

The sudden "scene-shifting" is necessary because Tane has to be both inside and outside the system of totemic signification. Inside, as the principle of articulation regulating exchange, 
but outside as well, since discontinuity in descent is required if the difference between clans is to be somewhere absolute and irreducible. Tane must die, then, in order to install the totem in its function of securing and maintaining the ordered play of difference. ${ }^{16}$ Language, similarly, might have been born all at once. What the poem suggests, however, is that whatever we might place at that "origin" - a natural sign, the word of God, a platonic idea, any transcendental signified — is actually the accomplishment of an operation: the type of "scene shifting" operation performed by the totem as an oxymoronic figure that is at once interior and exterior, plus and minus, presence and absence, at once purely itself and the structured rule of its play. The poem began by clearly locating two of those "sceneslinguistic and extralinguistic reality - but it also hinted at two more. A transgressive speaker, it seemed, himself would become unspeakable: a conflation of the linguistic and extralinguistic that recalls another contradiction at the heart of our experience of language. Language, of course, articulates a world it is discontinuous from, yet we are also aware that language is both a transpersonal and abstract system, and also a material product of the individual human body. The former is the realm of the well-spoken word, the latter a zone for expletives, for the inarticulate passions that drive the slippage and proliferation of meaning. Perhaps the last lines of the poem take us there. It is now, and for the very first time, that something implicit in stories of origin is made explicit: the name Tane, Tane Mahuta, is "womb-syllabled." The phrase allows us to reformulate the word-world relation drawn at the start of the poem. Previously, this was a two term relation: on one hand, the well-spoken word, on the other, the unspeakable, call it nature or extralinguistic reality. It is the phrase "womb-syllabled" that now stakes out that position, and the "unspeakable," this principle of violence that wrenches - perhaps even to devour - the word from its natural origin, is now a third term triangulating the two prior positions.

The Unspeakable 
"Tane, Tane mahuta"

(i) the name

(ii) the son

(iii) poet/reader
"Womb syllabled"

(i) the tree

(ii) the mother

(iii) the body

The unspeakable is what mediates the opposing terms, what makes language a totem. I suppose its best name might be something like the languageness of language or the figurativeness of figures, but if you recall the violence done to the body - perhaps an ongoing threat, perhaps an image of anyone's passage from infantine echolalia to the disembodied symbolic of a language system - another name suggests itself. The triangle is oedipal. At its apex write, "Papa" - a four letter word.

\section{MOTHER ROCK}

"The stone, the categorical effigy..."

-Wallace Stevens 17

"... and that old Dame

From whom the stone was named."

-Wordsworth 18

The place Curnow privileges above all others is the beach - that zone of arrival and departure, that set staged for the ritual encounter between territory and the one who would map it. "Dialogue with Four Rocks" — from the 1982 collection, You Will Know When You Get There -is a late variation. ${ }^{19}$ Its title and project seem close to Wallace Stevens. "The absence of the imagination had itself to be imagined," wrote Stevens, and Curnow seems to be imagining 
just that. ${ }^{20}$ His rock is a referent for some outcrop of territory but also a figure through which that territory is imagined as if in the absence of human mediation, as if on its own terms. It is an effort that must fail, but I think Curnow's poem arrives at that failure sooner than we might have expected, that it goes on to become another kind of poem.

The poem's first section begins:

High and heavy seas all the winter dropped the floor of the beach the whole mile exposing more rocks than anybody imagined the biggest surprise a reef the size of a visiting beast you have to walk round

This inert and alien wonder "disappears" as the poem continues to map it. It was there, no doubt anyone could have seen it, but as the speaker moves to a generalised present tense"the sea shovels away all that loose / land and shovels it back" —we find we do not know whether, for him, the reef is presently in view. Still, something smaller is underfoot:

a ball of sand stitched together with spun lupin and looping spinifex making it look natural little as you like to think nothing's either covered or uncovered for ever.

What had been figured as purely and simply present is now stitched together in the sandy, natural looking, overlay of language. The reef, previously this "thing," becomes the "nothing" of the closing lines-as if what might have been before one's eyes had been translated into the there and not there of its sign.

But something occurs before this figured supervention of language, this accommodation to the map. The speaker, trying to imagine the rock on its terms, regards it as an utterance or 
hieroglyphic of geological process, geological time.

a formation

out of the gut of the gales the noise the haze the vocabulary of water and wind

'answer'

the thing 'demands an

I know you do you know me?

And so,staring at the rock, the speaker hears (or heard) its silence as a form of communication. It is not quite a "Dialogue," or not yet, since what is exchanged in that moment is a glance without words, a glance pregnant with questions of and for subjectivity. "I know you do you know me?" This is the question asked by every momento mori; it is also the "language" in which one addresses-is addressed by-the new born.

But this glance, so suggestive of ends and beginnings, is not held. The poet will return to and amplify that moment but, so far, the most we know about it is its position in a plotted exposition of theme. At first, there was a reef-an item of territory, something to walk round or bump into-and the subject whose map it surprises. Then the glance, the close encounter, and third, the play of absence and presence that marks the reef's accession to language. The second section of the poem is set in a cave. It is the size of a small church and the speaker is inside, endeavouring once more to conceive the inconceivable. His conception takes the form of an analogy between his position inside the cave and what we might term the homuncular location of a "self" within the cavity of his skull. At first, the rock is presented anthropomorphically. It has a wig of trees and is "chapleted" with clematis and kowhai. It's spring and, under all that vegetation, the rock is "thinking big." Next, a reversal: the speaker's thought processes are naturalised in terms drawn from the external scene.

$\ldots$ if it

stoops to speak so to speak the word

of a stony secret dislodged 
the creator knows he's made it!

his mate matter

$$
\text { out of nothing }
$$

To the question, "I know you do you know me?" analogy answers, "I am like you and you are like me." It is enough to trigger a small avalanche of "language."

a tied tongue loosed the stony ghost

before all of us talking all

at once in our own languages

the parakeet's brilliant remarks

the fluent silences of the

eel in the pool

At this point, I am reminded more of the languages Doctor Doolittle wished to speak than that moment in which the reef posed its question. But if the terms of an analogy open no outside to language they may, pressed hard enough, stage something like an outside as an effect within language.

The section ends: "I think the rock / thinks and my thought is what is thinks." This analogy between subject and rock has the tautological structure of all anthropomorphisms: "I think the rock thinks, and what I think is what it thinks." It is also a chiasmus: "I think the rock thinks and what it thinks is me." The undecidability between these two readings is both a crisis for signification and for the subject whose "I," turning into stone, unsettlingly discovers evidence of its own materiality. This moment in language replays the moment of the unmediated glance between subject and object and replays, too, in its reciprocities and deathly reminders, the double register of that "I know you do you know me?"

I have suggested that the poem sets out, much as a Wallace Stevens poem might set out, to imagine the extralinguistic as if on its own terms. But the poem doesn't so much delineate a "nothing that is not there and the nothing that is" as envisage a more curious in-between place, not extralinguistic reality but not the real as articulated by language either. ${ }^{21}$ This space poses a threat to the "I," to the differentiation of subject and object, and, if this space 
comes to be associated with the transient materiality of the self, it would also seem to be more primordially known.
A rock face is creased in places in others cracked through to itself I have
never climbed though children sometimes do up to the chin of the cave below
I always look up though something else is always uppermost a cloud scuds
past the sun reappears yellow lichens ashy patches thicken sicken
on the skin of the face of the rock from spots the size of the iris of a mouse's eye to a smashed egg the rock is wetted by a weeping lesion
long after the rain stopped it looks down I look up a wink is sufficient.

If borders between subject and object are disturbed when the self can imagine itself as rocklike, something more extreme is at stake when the incorporeal materiality of rock is given a face whose "ashy patches" and "weeping lesions" evidence a sickening corporeality. Something inside the rock seeps into the outside; what ought to be firm and distinct is porous, slimy, corrupt; it is only water, but, for the speaker, it seems a distillation of everything that 
might turn his stomach. That such a horror should wear a face is one way to indicate a zone where subject/object distinctions fade into permeability. It is also, in the very giving of face and the disgust that accompanies that gesture, a shoring up of the boundaries whose collapse is being imagined. I shall explain why in a moment, but first, let us put a name to that face.

The third section of the poem tells us that the "I know you do you know me?" glance does not occur across the horizontal plane of adult eye contact. It is a perpendicular exchange: the speaker looks up, like an infant, at the eye looking down at him. And there is a final replay of that glance still to come: "recesses of mother / rock overhang me," writes the poet in the fourth section. If the enjambment suggests that matter is mater, it might also remind us that language, the symbolic realm "A Four Letter Word" associated with the paternal function, is also "womb-syllabled," developmentally underwritten by the pre-linguistic, the pre-symbolic.

I find it useful to consider this "mother / rock" not as an object but rather as the not-yetobject Julia Kristeva terms an abject. Her notion of abjection provides an account of how the infant, not yet a subject and still dyadically intervolved with its mother, comes to the threshold of his or her acquisition of language and identity. As a mechanism, abjection is a casting out by the infant of the pre-Oedipal mother, a formative evacuation and division of the notself that underpins the subsequent construction of a unified body image and, with the entry into language, of a self that can master symbolically coded oppositions between inside and outside, pure and impure, me and not-me. Not that abjection is ever over and done with: traces of the developmental "stage" persist in dietary taboos, rites of pollution and defilement, reactions to death and the sublime, in forms of psychosis and in the ordinary experiences (foul changing sheds, a fly in one's cup, a burgled house... ) where one finds oneself overtaken by revulsion or nausea. 22

The speaker registers precisely this affect when "ashy / patches thicken sicken on the skin of the face of the rock." But it is the very walls of his own body, the boundaries of his own 
self, that are threatened. If one detail-"spots the size of an iris" - suggests that such a collapse may be desirable (the iris is beautiful, alluring), the defensive nausea of "weeping lesions" quickly reaffirms the integrity of those boundaries. It would be inexact to say that the rock causes abjection. As Kristeva emphasises, "it ... is not a lack of cleanliness or health that causes abjection but what disturbs identity , system, order." ${ }^{23}$ Yet what does disturb identity, system, order is always already within identity, system and order: as the final section of the poem reminds us, death infects life and language is a system of arbitrary signs.

\author{
Memory is a stonier \\ place at the farm they called it \\ Rocky Gully blackberry \\ claws me back where I'm crawling \\ pistol-gripping the rifle \\ at arm's length after the hurt \\ hare my two bullets in its \\ body and couldn't reach it \\ where the third aimed blindly hit \\ home recesses of mother \\ rock overhang me and the \\ sun the rock offering no \\ choice of exit under the \\ one skin hare and hound I catch \\ myself listening for the shot \\ in the dark I shall not hear.
}

There ought to be something chancy or wild in a shot in the dark. But the speaker's shot, aimed however "blindly," is associated more strongly with the certain, the inevitable. Even so, the third bullet has ricocheted oddly, catching perhaps the hare, but also "recesses of mother / rock" and finally, though not yet, the speaker himself. It is as if the bullet's flight stitched together the beginnings and ends of the subject. Janus-faced, the abject mother/rock 
links what has gone - the pre-Oedipal pleasure of fusion with the maternal body-with what is still to come: the shot in the dark that announces the speaker's entropic return to an earlier state of things. That shot, of course, is death, but I think we might also hear it as the "report" of a word, a sound one always can say but never can write.

The end of a certain kind of writing might be to write the real as if on its own terms. The poet who tries to write the unwriteable must do so backwards, as it were, from a position of linguistic mastery always in advance of the moment he wishes to reach or recover. What he does reach we have seen, is never the pure referent but either a sacrifice made in its place or, as here, the thing itself figured as an abject referent, as "mother/rock." This is the hieroglyph of a kind of proto-writing that promises to join a thing and its name much as, in the pre-Oedipal space of abjection, mother and child are inextricably fused and joined. This is what appeals; it is also what cannot be countenanced. The iris of that maternal eye threatens to ossify whoever would catch its gaze. It would be to pre-empt one's "detour towards death" by means of psychosis. ${ }^{24}$ And so, the poet swerves away, finds it disgusting, sends a bullet home in an effort to kill it-but he can't. He can only regather his boundaries, and if we suppose that the swerve of abjection is, as it were, "back into" language, it is only to find that language has lost the naturalness within which he once found his place and identity. This is an assurance that might have been worth sacrificing for. Now, though, the assuring transparencies of language have become rock-like in writing. Its intransigent materiality speaks of the non-coincidence of a self and its signs, of death and of dying. But it may be that in the permanence of those traces we hear the report of another shot in the dark: not immortality, exactly, but (to vary a line) the way, for a poet, these dyings constitute his bloom. ${ }^{25}$

I think again of Lysimache and her predicament with economies of signification. No doubt 
she was right to refuse the mule drivers' request, but I have a hunch it might have got into the ritual all the same. I picture her, at a great age, still making the solemn procession, a procession that has long since been punctuated by a riotous moment in which the mule drivers would playfully repeat their request and the priestess would playfully refuse.

\section{Notes:}

Cited in Jonathan Z. Smith, "The Bare Facts of Ritual," History of Religions 20 (1\&2), 1980, p. 113. In what follows I am indebted to Smith's discussion of this passage and to the "rabbinical" question he poses: "What if the mule drivers had taken their drink without asking anyone and then were discovered? What then?" (p. 117).

Statement in James Vinson and D.L. Kirkpatrick eds., Contemporary Poets (New York: St. Martin's Press, 1985), p. 177.

Author's Note to Trees, Effigies, Moving Objects, Continuum (Auckland: Auckland University Press, 1988), p. 227.

"Obsessive Actions and Religious Practices." In The Origins of Religion, trans. James Strachey, Pelican Freud Library 13 (Harmondsworth: Penguin, 1985), p. 35.

"Landfall in Unknown Seas." In Collected Poems 1933-1973 (Wellington: A.H. \& A.W. Reed, 1974), pp. 136-39.

Freud's fullest commentary is in Introductory Lectures On Psychoanalysis, trans. James Strachey, Pelican Freud Library 1 (Harmondsworth: Penguin, 1973), pp. 301-3.

Alfred Korzybski's rule, cited in Gregory Bateson, Mind and Nature (New York: Dutton, 1979), p. 30.

For many such jokes, see Susan Stewart, Nonsense (Baltimore: Johns Hopkins University Press, 1979).

"A Four Letter Word," Continuum, op. cit., pp. 215-16.

Jean-Jacques Lecercle, Philosophy Through The Looking Glass (London: Hutchinson,1985), pp. 25-26, 15. 
Ferdinand De Saussure, Course in General Linguistics, trans. Wade Baskin (Bungay: Fontana, 1974), p. 120.

For a fuller discussion of these issues, see Paul De Man, "The Resistance To Theory," in David Lodge ed., Modern Criticism and Theory (London: Longman, 1988), pp. 355-71. 115. pp. 99-100.

And hence, too, my preference for a syncretic reading. Our "Kauri Clan" is unlikely to have been Maori. As Lévi-Strauss comments, "New Zealand has never been mentioned as offering typical examples of totemism ... . It is because the animals, vegetables and minerals are genuinely thought of as [genealogical] ancestors that they cannot play the part of totems." (Ibid.) For an interesting alternative reading of the poem - one that pays rather more attention to the Maori creation myth - see Terry Sturm, "Fictions and Realities: An Approach to Allen Curnow's Trees, Effigies, Moving Objects," World Literature In English, 14 (1), pp. 25-49.

"Chocorua To Its Neighbour," The Collected Poems of Wallace Stevens (London: Faber, 1984), p. 300.

The Prelude, ed. J.C. Maxwell, (Harmondsworth: Penguin, 1972), p. 74.

Reprinted in Continuum, pp. 91-94.

"The Plain Sense Of Things," The Collected Poems of Wallace Stevens, op. cit., p. 503.

For a discussion of abjection see, Julia Kristeva, Powers of Horror, trans. Leon S. Roudiez (New York: Columbia University Press, 1982).

Ibid., p. 4. trans. James Strachey, Pelican Freud Library 11 (Harmondsworth: Penguin, 1984).

Cf. "Spectacular Blossom," Collected Poems 1933-1973, p. 193. 